\title{
The Madness of Europe, Being Attached to It
}

\author{
Loïc Azoulai*
}

These days, the madness of Europe seems to break out. Public life is filled with statements such as, "our way of life is a distinctive one; it is not up for negotiation." Back in 1992, George W. Bush uttered the words: "The American way of life is not up for negotiation. Period." This was during the Earth Summit in Rio de Janeiro, in reaction to pressures to act in response to climate change. In Europe, we are becoming increasingly used to hearing this form of words.

These words come from where we expect them to come, identity politics: "Brussels wants to dilute and replace the people of Europe! It throws our way of life, our culture, and everything, what separates us and differentiates us Europeans from other nations of the world ... Europe and Hungary are in the middle of a war between civilizations. We face a migration that upsets our order and puts at risk our way of life. Without preserving our way of life, everything will lose meaning." Thus spoke Viktor Orbán in Budapest on March 15, 2018. But these days, this also extends to conservative political leaders. In a speech at Lancaster House on January 17, 2017, Theresa May endorsed the sentiment that the institutions of Europe are a threat to traditions, values, and lifestyles that people hold dearly. She claimed: "Our political traditions are different ... and as a result supranational institutions as strong as those created by the European Union sit very uneasily in relation to our political history and way of life." Some intellectuals even dare saying: "Majorities (not just minorities) have an ethnicity too, a way of life that many want to preserve and fear of not being able to do so." This is David Goodhart in Prospect, a British magazine, on March 18, 2018. We come upon such words almost every day over whatever claim related to the identity or integrity of the society, a territory, or a social group. They flourish on many fronts. In his "Independence Speech" on October 10, 2017 at the Parliament of Catalonia, Carles Puigdemont said that "over the last years, we have witnessed a hurtful disregard for our language, our culture and the way of being and of living of our land." Iman Amrani, commenting on the Achbita decision of the European Court of Justice in The Guardian on March 14, 2017, wrote: "For its wearers the hijab is a core part of their way of life, linked to the way they choose to practice their faith. It is not up for debate." These are convenient words, but these words form consistent discourses, and these discourses constitute the web of meaning in which we are embedded. Take note: All that is real.

Recently, European leaders have picked up the very same words. In his State of the Union Address on September 14, 2016, then President of the European Commission Jean-Claude Juncker declared that he wanted a "better Europe," which is "a Europe that preserves the European way of life": "I am convinced the European way of life is something worth preserving." Why state this? "Our European Union is in an existential crisis ... Never before I have seen so much fragmentation, and so little commonality in our Union ... I have the impression that many

\footnotetext{
${ }^{\star}$ Loïc Azoulai, lawyer and legal scholar, was born in 1971. Formerly chair of European law at the European University Institute (2010-2015) and référendaire at the European Court of Justice, working with the Advocate General Miguel Poiares Maduro (2003-2006). He is currently professor at Sciences Po Law School, Paris. His work is entirely devoted to the study of the laws of Europe.
}

(c) The Author(s) 2020. Published by Cambridge University Press on behalf of the German Law Journal. This is an Open Access article, distributed under the terms of the Creative Commons Attribution licence (https://creativecommons.org/licenses/by/4.0/), which permits unrestricted re-use, distribution, and reproduction in any medium, provided the original work is properly cited. 
seem to have forgotten what it means to be part of this Union of Europeans." The theme is that the Union should exist as much as a lived and felt experience as it is an institutional project. The new President of the Commission, Ursula von der Leyen, embraced this shift in the self-understanding of the European Union by appointing a vice-president "for protecting our European way of life." On September 10, 2019, she announced that the new portfolio would cover a wide range of issues, including migration, health, security, culture, sport, education, and integration. Something in this, masquerading as an institutional initiative, quickly piqued the indignation of many. The title was then changed to "promoting the European way of life." Justification was also given. We would be in the middle of a cultural, political, and moral struggle: "We cannot and must not let others take away our language from us. This is also part of who we are. We should not allow these forces to hijack the definition of the European way of life ... We should be proud of our European way of life in all of its forms and dimensions." The European leaders think of the European way of lifethe institutions and practices associated with European integration-as very much worth defending. But not because it is the outcome of a unique institutional construction, and not even because it reflects the great Single Market's achievements. These leaders suggest that these institutions and practices incorporate or reflect something deeper or grander than European integration itself: A commitment to values and to the notion of an open and stable society. Juncker again said: "An integral part of our European way of life is our values."

This narrative-for it is one-is, and is meant to be, impressive, but it fails to convince. Our current failure to attain a consensus on the liberal values that emerged in Europe during the Enlightenment-and that have found shelter in post-war European institutions-should not, in itself, make us doubt the centrality of these values. We know how non-liberal, socio-political arrangements may badly affect the most intimate area of citizens' lives. We know of sinister and thoughtless words enflaming social passions of resentment. We Europeans have had too much of this experience already. So why does this response to the current situation strike me as the wrong one? For one reason only: Resorting to European values is completely missing out on a growing sentiment among various groups of people across Europe that the European Union-its machinery, policies, and laws - are both too remote from pressing needs, failing to provide basic goods such as economic and social welfare, security, or healthy environment, and too intrusive in people's everyday lives - destabilizing entrenched habits, values, and beliefs. In other words, they are, all at once, too remote and too intrusive. People want the EU to deliver more, and they want to be freed from the EU; strange Europeans that they are. But there is more: This widely shared ambivalence is not a product of broad conceptions about the nation, the society, or the nature. It emerges from how individuals represent to themselves their concrete conditions of existence, from how they relate to their habits, values and beliefs - the everyday life. This ambivalence touches on people's position in society, their place in the world, and their condition on earth. Madness is to be blind to this. Madness is to be blind to the crises of the everyday in European societies that manifests in a number of ways, from disagreement to protest, from disillusion to a sense of disorientation or despair.

In the face of this, an abstract defense of European values turns out to be untenable, if not absolutely unbearable. For one thing, it may be seen as yet another way of protecting the Union institutional sphere from "real" society, from genuine social and political conflicts. The values act as refuge for EU politics and EU law: A smokescreen for the usual business of making partial compromises among public officials, or of exhibiting self-standing legal principles in the courtroom. Fighting for liberal values in social life or legal argumentation is commendable. But reliance on values is not a mode of governance. In the end, this appeal to values is an exercise in legitimation of the EU's own policy preferences, which merely helps advance the institutional agenda. The result might very well be that people feel excluded from the "good" institutional world. In some southern parts of Europe, it is on behalf of a "core" European value-the value of financial, budgetary, political, and social stability - that individuals have been subject to the severity of austerity measures, which have led to extreme material poverty. 
How can we prompt the European Union and its institutions to reconnect with society, its actual practices, beliefs, and collective ideas? Is this to say that we should defer to any public sentiment that relies on cultural or identity-related claims? As much as we should not be blind to the institutional values game, we know that social feelings too are vulnerable to distortion, dissolution into abstraction, and ideological exploitation as well. A particular form of political struggle over ways of living - in society, in Europe, on earth-has emerged recently. It involves representations rather than policy proposals. Some call it "affective polarization." It relies on the fact that people position themselves according to group and community identities rather than ideological disagreements. This is pervasive in the political sphere as well as in the wider public. The last European elections bear witness. This kind of political struggle functions according to a specific logic in which the force of representations does not depend on their truth-value, which is to be measured by the degree to which they represent the kinds of lives that are actually threatened in Europe and the exact extent to which these lives are threatened. In Europe today, public sentiments are easily made subservient to partisan interests oriented towards an abstract goal that distorts the actual life of individuals and social groups in need of protection-be it Boris Johnston's "free trade," Matteo Salvini's "health and security," or Jarosław Kaczyński’s "people’s dignity."

The "promotion of the European way of life" political emblem is being caught in this dangerous game. When placed in relation to the issue of migration, the risk is that we may be witnessing a loss of connection to common values and the sense of reality. We have to realize that when we structure the system of migration policy in Europe, it is the lives of migrants that we structure or de-structure. In the representation of life encapsulated in the ambiguous emblem of the "European way of life," migrants are mostly seen as threats, not worthy of trust, or else as victims to be placed in the hands of institutions and institutional cooperation. In any case, they are at a distance from "us" and from "our" societies. Their life_or death—looks like what Musil depicts, in the indelible opening scene of The Man Without Qualities, as a banal accident, "the horrible happening [that] could be fitted into some kind of pattern, so becoming a technical problem that no longer concerns us," so that "people walk on with the almost justifiable impression that what has occurred is a purely legal and institutional event."

We European lawyers who treasure the institutions of Europe should realize that we are not more in touch with the web of practices and relationships, orientations, and modes of behavior that constitute the whirl of social life in Europe than are the Eurosceptics and other Leavers. We have been driven for too long by the ambition to establish the set of rules, principles, and ideals on which the whole European construction could be based-standing above the fray of ideological, political, social, and cultural differences whilst shaping them. We have been busy with this noble task: Building a Common Market, a New Constitutional Order, and the Area Without Internal Frontiers. The great task of building; it still retains some grandeur. But the grandeur has fallen. The call for a new grand structural plan for the European Union has lost its appeal. The call to deconstruct, to disaffiliate from membership, or even to struggle for independence, appears inspiring and appealing to many Europeans of our times.

These days even Eurosceptics say they feel deeply committed to Europe. Certainly, we are right that the European institutions have served us well-in improving our living conditions, in generating peaceful and productive relationships, and in smoothly managing the ties of our interdependence - and no set of arrangements within the present scope of institutional imagination seems likely to serve us better. But the other side is right that the utility of the European experience is somewhat impugned by the fact that it has been built out of social distress, political distrust, moral divide, and cultural destabilization.

It takes a certain dose of irony to realize the contradiction in which we live in Europe today. Torn as we are between a widely shared claim based on re-appropriation of one's existenceroughly put in these terms, "we the people want to take back control of our lives," and the awareness, or sometimes the willful blindness, that our existences and our coexistence depend, to a larger extent than ever before, upon a set of interconnections between markets and societies, 
material and technological resources, and social and moral guarantees, which are structurally based on EU regulations and institutions. The UK's Brexit is a perfect illustration of this. But it would be a mistake not to recognize it, in different idiosyncratic ways, in other European countries. The contradiction between these two intractable realities-or between these two uncompromising perceptions - characterizes the perfect madness of our situation. It gives our madness its prevailing shape: A sense of disorientation, as well as a need to find again a sense of orientation.

This seems to me to be the challenge of our time. It asks us to be both pragmatic in reassessing the real benefits and costs of integration and responsive on the existential terrain, rather than either re-examining the worth of our institutions - as critics on the left suggest we should-or stoutly affirming the unique cultural identity of Europe as critics on the right suggest we must. Amartya Sen wrote that "the importance of human lives, experiences and realizations cannot be supplanted by information about institutions that exist and rules that operate ... [T] he realized actuality goes well beyond the organizational picture, and include the lives that people manage or do not manage - to live." What was then a brilliant methodological suggestion turns out to be a pressing political, legal, and intellectual requirement. We need to take stock of the kinds of lives people manage-or do not manage - to live, given the institutions and the laws of Europe. Furthermore, it is by reconsidering the conceptual choices by which we describe and analyze these lives, the social practices people are engaged in, the forms of attachment they develop, the frames of signification they put in place, that we will be able to regain a sense of the reality and thereby recapture a form of collective agency.

The genius of the Union and its law is no longer in them being engaged in an order-building enterprise. It is no longer to produce forms of subjectivity and social patterns of action that are instrumental to EU policy goals. We should remove any form of institutional constructivism that is left in it. Rather, we should be prepared to test the constructions that are part of the EU's legacy against the clusters of existence that result from these constructions as a means to adjust them. EU law has become a privileged site for individuals with multiple affiliations or identitieswhether they are nationality bonds, affective attachments, or professional ties. But it has failed so far to work as a shelter for people who seek to assert practices and forms of existence that stem from EU law constructions whilst exceeding them, flourishing outside the ambit of existing legal categories: Individuals in limbo situations_-non-removable irregular migrants, non-deportable economically non-active Union citizens, persons in difficult labor situations, constantly navigating between economic activity and inactivity; individuals problematically embedded into different spheres of activities - such as the nexus family/profession or the nexus religion/profession; individuals and groups attached to threatened forms of life, ecosystems such as forests. This, then, is the challenge: To find a common place for these kinds of lives and forms of life. The EU experience started as a disruptive device, problematizing attachments to the native soil, taming excessive assertions of identity, displacing established social and cultural norms. If the EU is to continue, it should worry about finding a place or a soil for these lives in Europe. These are none other than our everyday lives. It is only in this sense that the Union and its law will be seen as a guarantee of existence for disoriented Europeans.

Cite this article: Azoulai L (2020). The Madness of Europe, Being Attached to It. German Law Journal 21, 100-103. https:// doi.org/10.1017/glj.2019.104 